\title{
Lean vs. Obese Mice: The Ventral Prostate Revisited
}

\author{
Ratones Magros vs. Ratones Obesos: Revisión de la Próstata Ventral
}

Fabiane Ferreira Martins ${ }^{1}$; Mariano del Sol ${ }^{2}$; Marcia Barbosa Aguila ${ }^{1}$ \& Carlos Alberto Mandarim-de-Lacerda ${ }^{1}$

MARTINS, F. F.; DEL SOL, M.; AGUILA, B. M \& MANDARIM-DE-LACERDA, C. A. Lean vs. obese mice: The ventral prostate revisited. Int. J. Morphol., 35(2):403-412, 2017.

SUMMARY: Obese mice (C57BL/6J-ob/ob) do not express leptin and develops hyperphagia, decreased energy expenditure, obesity, hyperglycemia, hyperinsulinemia, hypothermia, and infertility. Obesity causes reproductive dysfunction with negative impacts on prostatic structure and fertility. We aimed to compare the structure and molecular aspects of the ventral prostate between of lean and obese (ob/ob) mice. Three months old male lean and obese mice had their prostates dissected and prepared for light microscopy and immunofluorescence. In comparison to the lean mouse, the obese mouse showed a substantial structural modification in the ventral prostate starting with an atrophy of the prostate ventral lobe. Histologically, the acini showed a reduction in size, and in the lumen, we found a mixed secretion PAS positive and negative. Epithelial changes consisted of a hypertrophied acinar epithelium with intraepithelial neoplasia focuses. Also, we observed a marked expression of PCNA and Caspase 3 in the epithelium indicating even cellular proliferation as cell death. The stroma showed a high activity of the extracellular matrix remodeling with marked deposition of collagen fibers and smooth muscle cells. Around the ventral region, we observed an increase in the presence of adipose tissue. The expressions of interleukin 6 and tumor necrosis factor alpha were present in the ventral prostate of the obese mice indicating inflammation. In conclusion, obesity negatively modulates prostate in ob/ob mice, directly affecting cellular and structural mechanisms necessary for the maintenance of prostate and reproductive structure.

KEY WORDS: Collagen; IL6; TNFalpha, alpha-actin; Reproduction; ob/ob mouse.

\section{INTRODUCTION}

Human and rodents share structural and functional similarities in the prostate, being the ventral lobe the most used in rodent studies. In the ventral prostate, the stromal compartment presents cells (fibroblasts, myofibroblasts, vascular endothelial cells, and smooth muscle cells), which secrete growth factors, produce extracellular matrix, and express androgen receptors, estrogen receptors, adrenergic receptors and 5-alpha-reductase (Berry et al., 2008).

The homozygous C57Bl/6J-ob/ob mice, carrying a recessive mutation in the gene that encodes leptin is a known model of obesity, resulting in a defect in leptin production, causing ob/ob mice to overeat and decrease energy expenditure, which in turn leads to morbid obesity (Martins et al., 2017). Also, ob/ob mice have insulin resistance, hyperglycemia, hyperinsulinemia, hypothermia and infertility (Won et al., 2016).

Androgens are well established to be centrally involved in the regulation of prostate growth, having a dual ability to stimulate proliferation and inhibit cell death in the glandular epithelium (Justulin et al., 2008). Male obesity may be associated with hypogonadism. The situation results in hypogonadotropic hypogonadism, reduction in sex hormone binding globulin (SHBG) production by the liver, and greater adipocyte aromatase activity leading to an increase in the conversion of testosterone to estradiol resulting in the altered hypothalamus and pituitary negative feedback (Chambers \& Richard, 2015).

\footnotetext{
${ }^{1}$ Laboratory of Morphometry, Metabolism, and Cardiovascular Diseases, Biomedical Center, Institute of Biology, State University of Rio de Janeiro, Rio de Janeiro, Brazil;

${ }^{2}$ Doctoral Program on Morphological Sciences, School of Medicine, Universidad de La Frontera, Temuco, Chile.

Funding: The Laboratory of Morphometry, Metabolism, and Cardiovascular Diseases is supported by the Conselho Nacional de Desenvolvimento Científico e Tecnológico, CNPq [grant number 302.154/2011-6]; and the Fundação de Amparo à Pesquisa do Estado do Rio de Janeiro, FAPERJ [grant number E-26/201.186/2014]
} 
We aimed at the study a regard focused on the structure and function of the ventral prostate comparing the lean and the obese mice in this attractive model of obesity.

\section{MATERIAL AND METHOD}

Animal care and handling. We used mature animals at three months of age ( $n=10 /$ group). The C57BL/6J mice were used as a control (lean). The C57BL/6J-ob/ob mice were purchased from Experimental Models Development Center for Biology and Medicine (CEDEME, São Paulo, SP, Brazil), from a colony derived from the Jackson Laboratory (B6. V-Lepob/J, stock no. 000632, Bar Harbor, ME, USA). In this project, the procedures adopted were approved by the local Ethics Committee for Animal Experimentation of the State University of Rio de Janeiro (Protocol Number CEUA/010/2016) in agreement with the current guidelines for animal experimentation (NIH Publication number 85-23, revised 1996). The animals were maintained in ventilated cages under controlled conditions in the Nexgen system (Allentown Inc., PA, USA), $20 \pm 2{ }^{\circ} \mathrm{C}$ and $12 \mathrm{~h} / 12 \mathrm{~h}$ dark/light cycle, with free access to food and water.

Euthanasia and gross anatomy. The animals were intraperitoneally anesthetized with $150 \mathrm{mg} / \mathrm{kg}$ sodium pentobarbital and accommodated in a supine position on the dissection board. An incision was made in the abdominal region in the caudal direction, and the skin and subcutaneous tissues were cut to expose the prostate. The prostates were removed and meticulously dissected using a stereomicroscope (Hund, Helmut Hund GmbH, Wetzlar, Germany).

Prostate structure: Rapidly, the organs were fixed by immersion in $4 \%$ paraformaldehyde in phosphate-buffered saline for $24-48 \mathrm{~h}$, then dehydrated with a graded series of ethanol, clarified in xylene and embedded in Paraplast Plus (Sigma-Aldrich, St Louis, MO, USA). Sections $3-\mu \mathrm{m}$ thick were stained with hematoxylin-eosin (HE), periodic acidSchiff (PAS), Masson trichrome, and Sirius red with the standard protocols (Kiernan, 1999). Digital images were obtained with a Nikon microscope, model 80i, and a DSRi1 digital camera (Nikon Instruments, Inc., New York, USA).

Other $5-\mu \mathrm{m}$ thick sections were submitted to citrate buffer, $\mathrm{pH} 6$, at $60{ }^{\circ} \mathrm{C}$ for $20 \mathrm{~min}$ for antigen retrieval, glycine $2 \%$, and blocking buffer (PBS/5 \% BSA). A double-labeling protocol was used to investigate the proliferating cell nuclear antigen (PCNA) and caspase3, tumor necrosis factor (TNF) alpha and Interleukin (IL) 6, type I collagen I (Coll-I) and smooth muscle alpha-actin (alphaactin). The sections were incubated overnight at $4{ }^{\circ} \mathrm{C}$ with:

a) Rabbit anti-PCNA antibody diluted 1:50 (SC-7907; Santa Cruz Biotechnology), and mouse anti-Caspase3 (NB-500-210; Novus Biologicals) diluted 1:100, in $\mathrm{PBS} / 1 \% \mathrm{BSA}$

b) Goat anti- TNFalpha antibody diluted 1:100 (SC-1350; Santa Cruz Biotechnology), and rabbit anti-IL6 (AB1423; Millipore) diluted 1:50, in PBS/1 \% BSA

c) Rabbit anti-Coll-I antibody diluted 1:100 (AB-292; Abcam), and mouse anti-alpha-actin (AB-7817; Abcam) diluted 1:100, in PBS/1 \% BSA.

Further, sections were incubated for $1 \mathrm{~h}$ at room temperature with fluorochrome-conjugated secondary antibody anti-rabbit IgG-Alexa 488 and anti-mouse IgGAlexa 546 (Invitrogen, Molecular Probes, Carlsbad, CA, USA), diluted 1:50 in PBS/1 \% BSA. After rinsing in PBS, the slides were mounted with Slow Fade Antifade (Invitrogen, Molecular Probes, Carlsbad, CA, USA). Digital immunofluorescence images were obtained using confocal microscopy (Nikon Confocal Laser Scanning Microscopy - Model C2; Nikon Instruments, Inc., New York, USA).

\section{RESULTS}

Gross anatomy of the prostate. In mice, the prostate is composed of four distinct lobes around the urethra (ventral, anterior, lateral and dorsal) based on their orientation and location (Figs. 1A, C and E). The ventral prostate surrounds the urethra bilateral and caudal to the urinary bladder (Fig. 1A). In obese mice, the separation of lobes of the prostate was less evident. In comparison to lean mice, obese mice had atrophied prostatic lobes, especially in the ventral prostate (Figs. 1A-F).

Histology and Immunofluorescence. In lean mice, the ventral prostate acini presented normal size and diameter, exhibiting epithelium of the simple type, which cells ranged from cuboid to columnar. In obese mice, we observed atrophy of the ventral lobe (Fig. 2A-B), consisting of smaller and reduced acinar structure compared to the lean mice (Figs. 3A-C). Also, the acinar epithelial cells showed hypertrophic characteristics, with irregular nuclei and a large cytoplasm (Figs. 3D-E). Invaginations exhibiting papillary appearance were observed in some regions of the acinar epithelium (Fig. $3 \mathrm{E})$, and some acini showed an intraepithelial cell mass with 
proliferative characteristic, indicative of prostatic intraepithelial neoplasia (PIN) (Figs. 3F-G). Also, in obese mice more than in lean mice, PCNA and Caspase 3 were positive in the ventral prostate, indicating proliferation and cell death acinar activity (Figs. 4A-F).

In the lean mice, the secretion into the acini was predominantly PAS positive. Conversely, in the obese mice the secretion was mixed, either PAS positive and negative. Also, we observed secretory vesicles detached from the apical portion of the cytoplasm characterizing apocrine type secretion (Figs. 5A-C).

In the lean mice, the stromal region of the ventral prostate consisted of layers of collagen fibers and smooth muscle cells arranged around the acini and blood vessels (Figs. 6A, C and E). In the obese mice, we identified an increase of the stromal the deposition of collagen fibers (Figs. 6B, D and F). The type I collagen and alpha-actin smooth muscle were abundant in the stroma of the ventral prostate of the animals (Figs. 7A-F). Also, in the obese mice, we found a high amount of white adipose tissue in the ventral prostate (Fig. 8A-C), and an inflammatory activity mediated by a high expression of IL6 and TNFalpha (Figs. 8D-F).
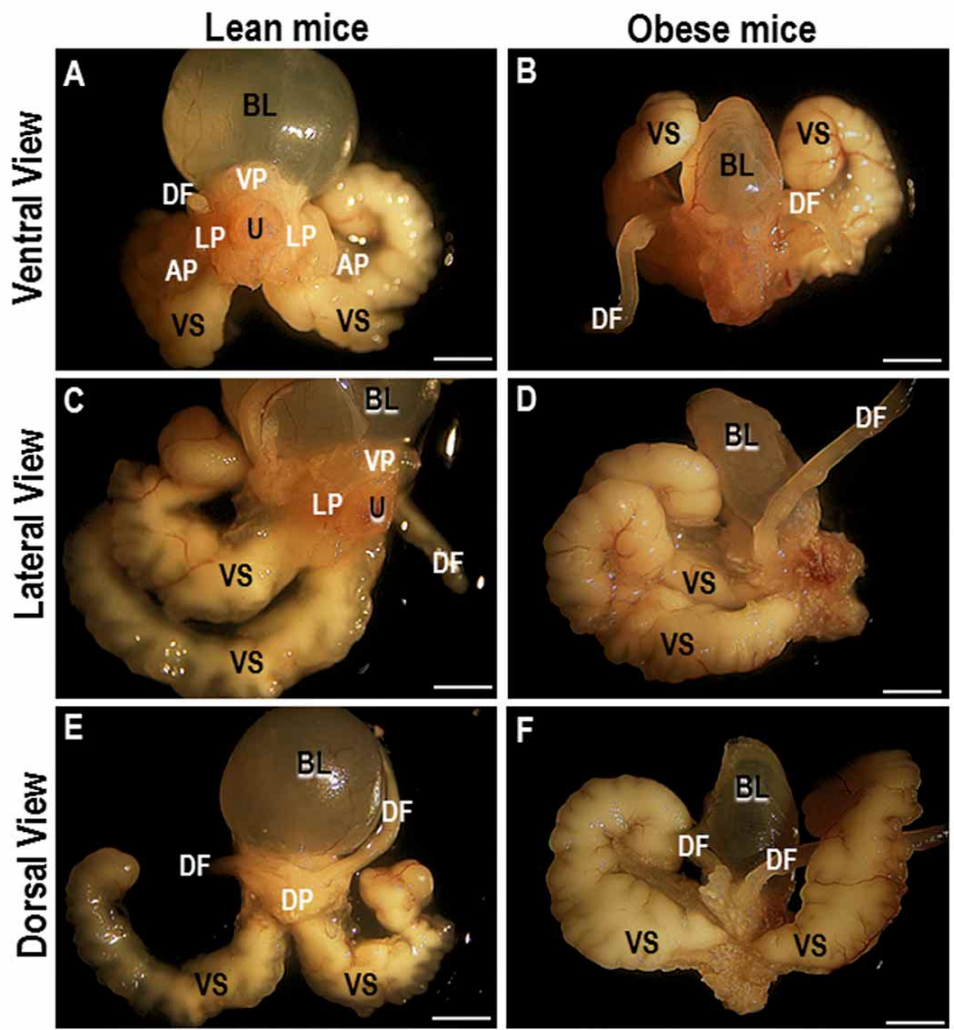

Fig. 1. Differences between the gross anatomy of the prostate of lean $(\mathrm{C} 57 \mathrm{BL} / 6 \mathrm{~J})$ and obese $(\mathrm{C} 57 \mathrm{BL} / 6 \mathrm{~J}-\mathrm{ob} / \mathrm{ob})$ mice. Note atrophy in the ventral prostate of obese mice. VP- ventral prostate; LP- lateral prostate; APanterior prostate; DP- dorsal prostate; VS - seminal vesicle; U - urethra; DF- deferens ducts; BL- urinary bladder. Scale bars: $1 \mathrm{~mm}$.

\section{Lean mice}

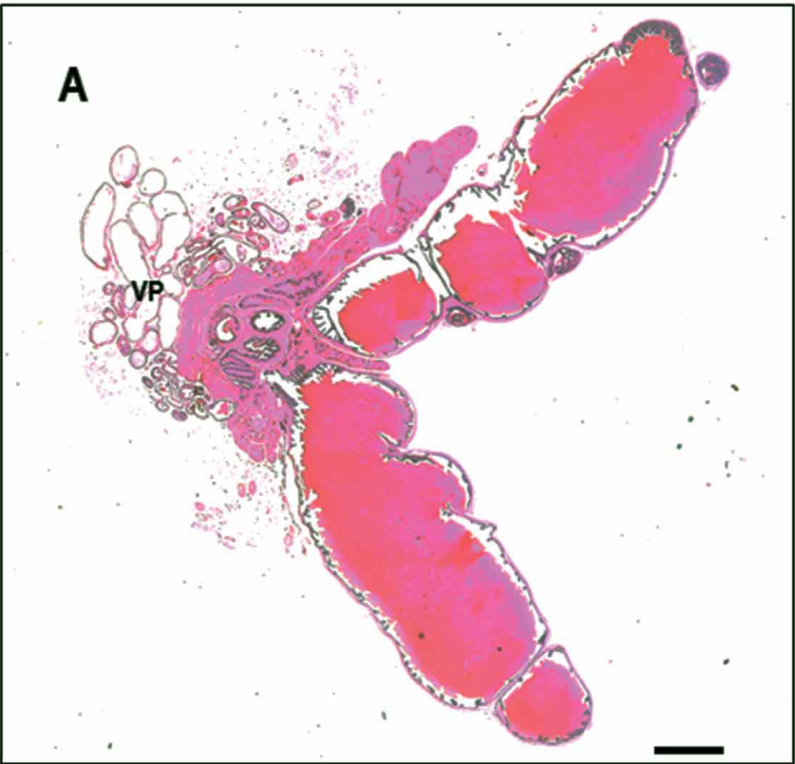

\section{Obese mice}

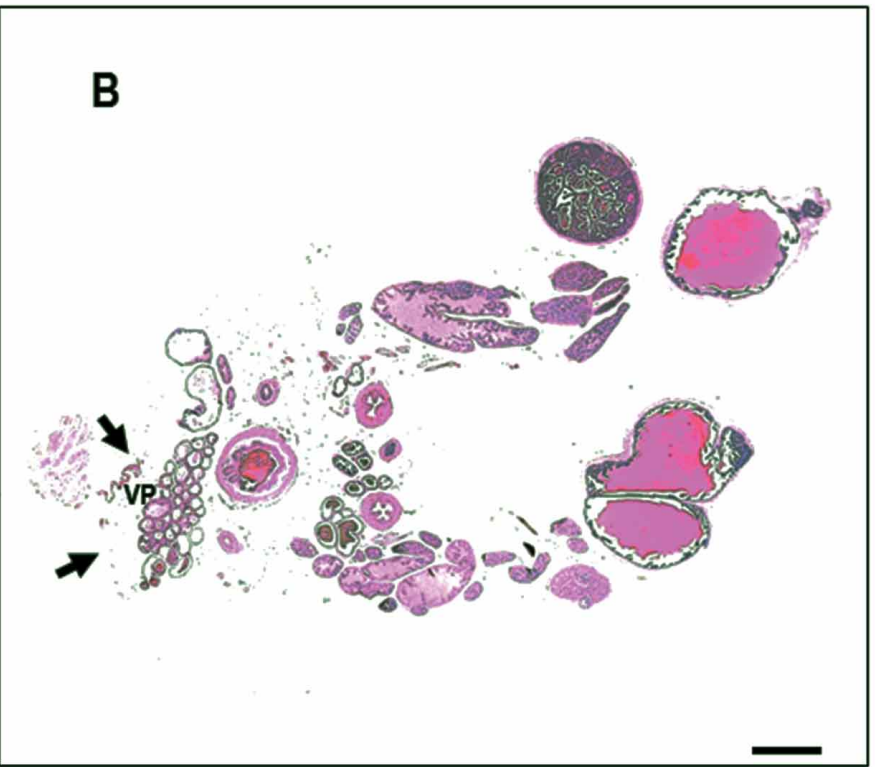

Fig. 2. Histology of the prostate of lean (A) and obese mice (B). Overview.

Note atrophy in the ventral prostate of obese mice (arrows). PV- ventral prostate. Hematoxylin-eosin. Scale bars: $200 \mu \mathrm{m}$. 

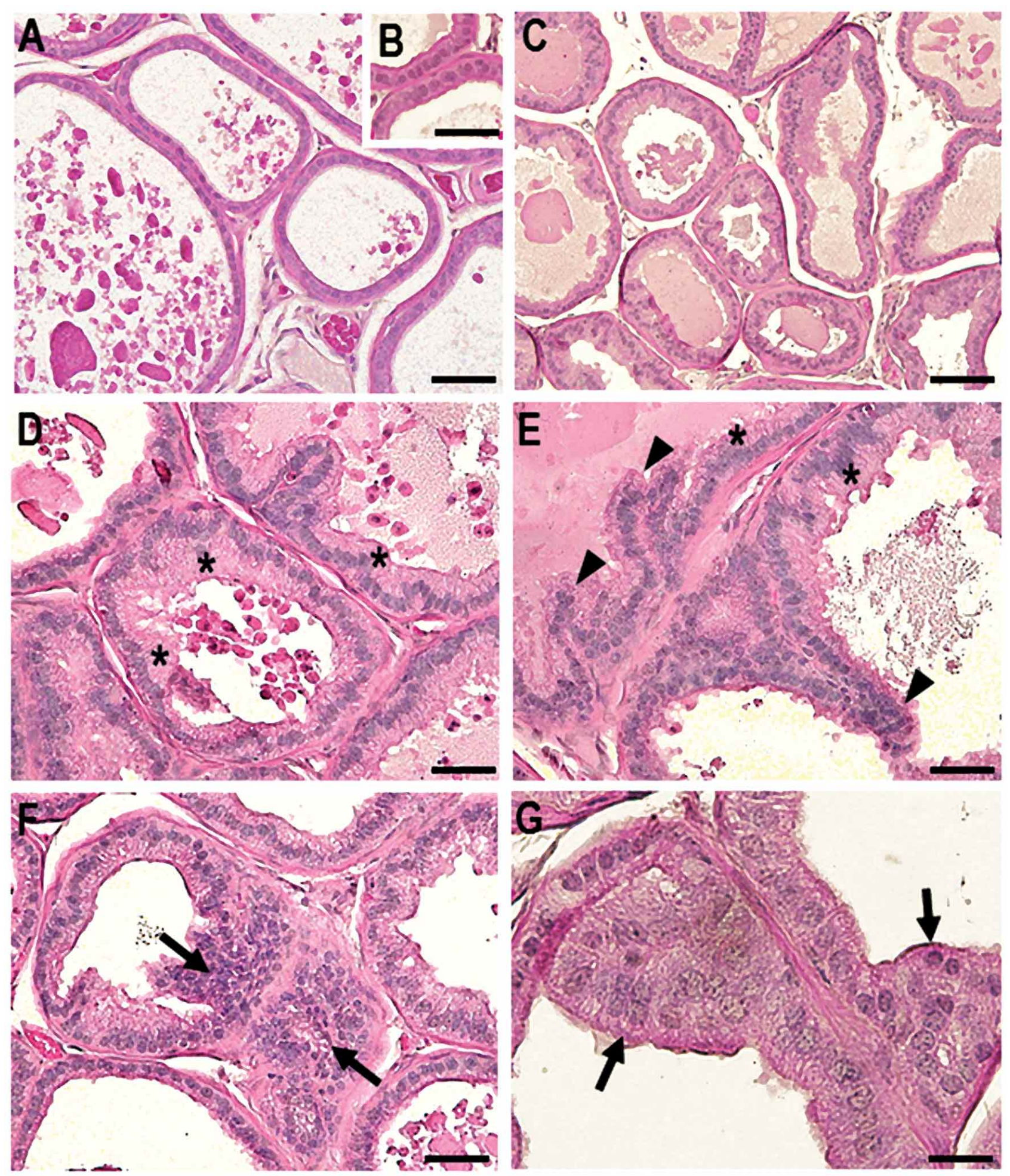

Fig. 3. Histological sections of the ventral prostate of lean (A-B) and obese mice (C-G). Note acini and epithelium of normal histology in the prostate of lean mice (A-B). Observe in obese mice: atrophied acini with the hypertrophic epithelium (asterisks) (C-E). Papillary invaginations in the epithelium (arrowhead) (E); intraepithelial proliferative mass (suggestive of prostatic intraepithelial neoplasia, PIN) (arrows) (F-G). Hematoxylin-eosin. Scale bars: A and C: $20 \mu \mathrm{m}$; B and D-F: $10 \mu \mathrm{m}$; G: $5 \mu \mathrm{m}$. 

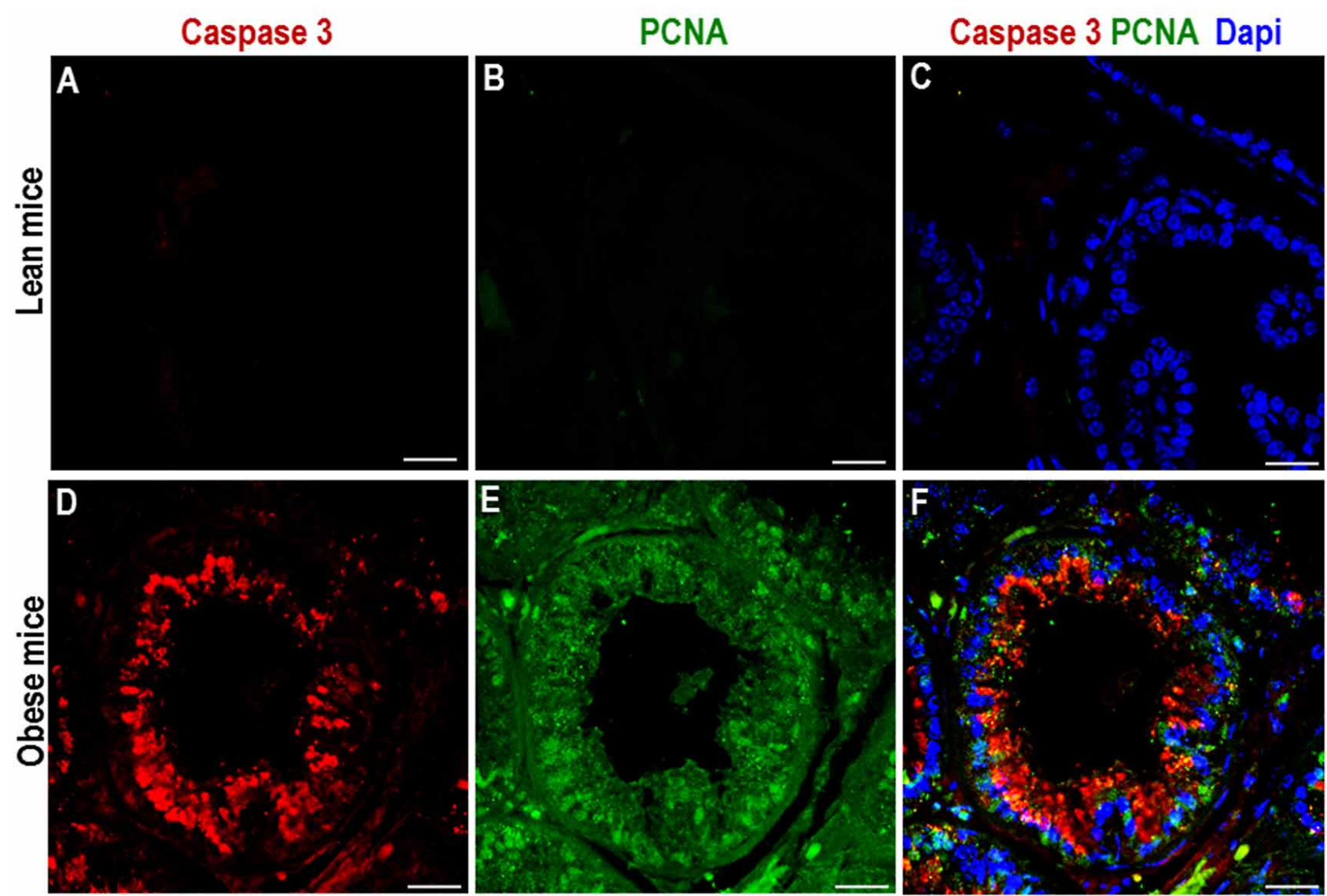

Fig. 4. Immunofluorescence of the ventral prostate of lean (A-C) and obese mice (D-F) for proliferation (PCNA) and cell death (Caspase3). Note the expression of PCNA and Caspase 3 in the prostate of obese mice. Scale Bars: $10 \mu \mathrm{m}$.
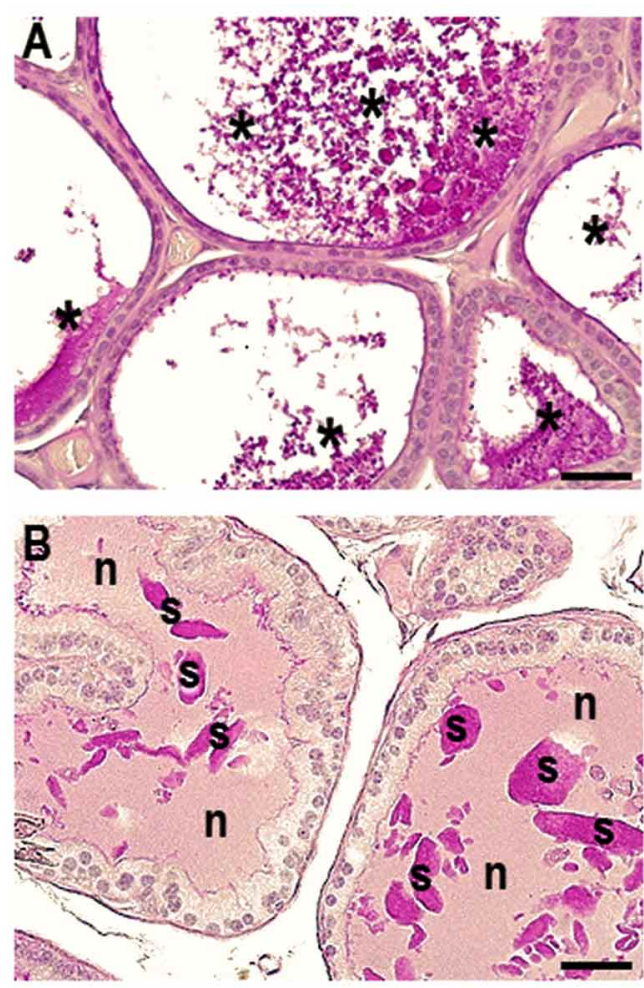

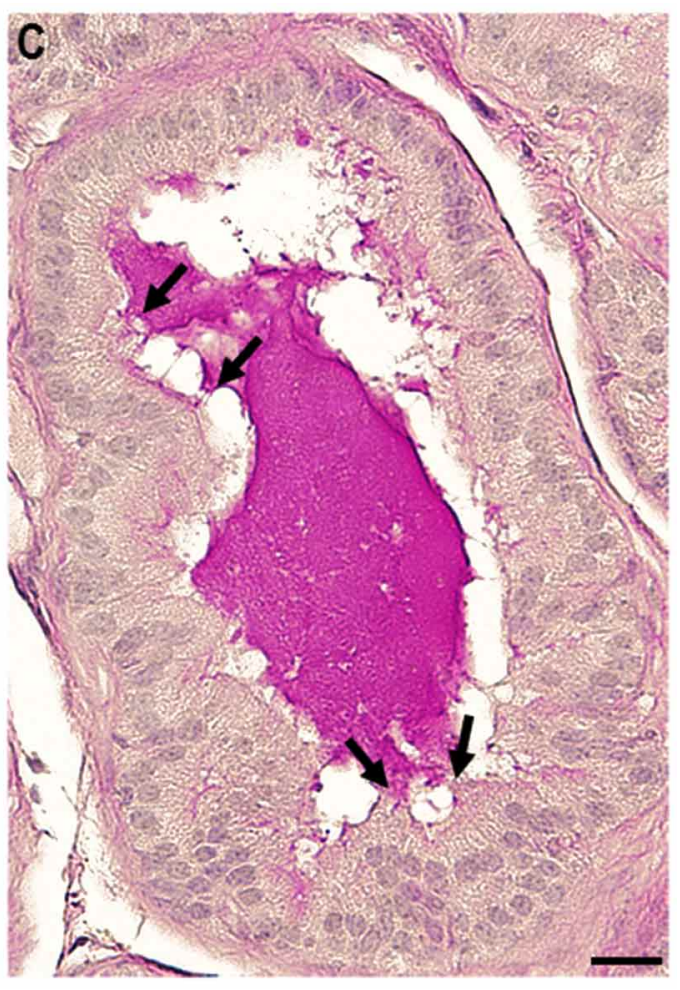

Fig. 5. Histological sections of the ventral prostate of lean (A) and obese (C-D) mice stained by periodicacid-Schiff (PAS). Note positive and granular PAS type secretion in the acini of lean mice (asterisks) (A). In the obese mice: acini filled with the secretion of the mixed type, positive (s) and negative PAS of fluid aspect (n) (B). Secretion of the apocrine type (arrows) (C). Scale bars: A: $20 \mu \mathrm{m}$; B: 10 $\mu \mathrm{m} ; \mathrm{C}: 5 \mu \mathrm{m}$. 

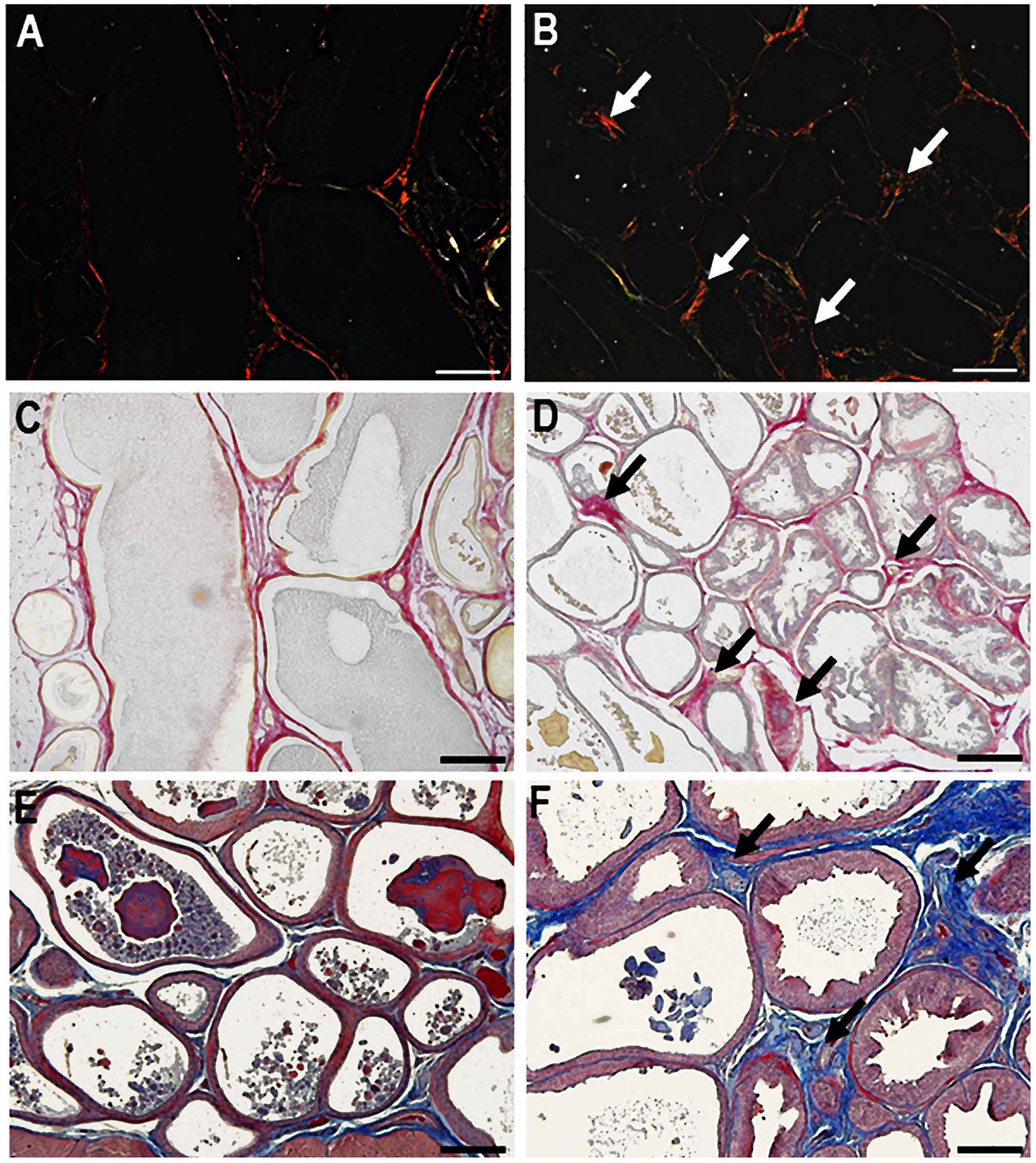

Fig. 6. Histological sections of the ventral prostate of lean (A, C and E) and obese (B, D and F) mice stained with Sirius red - polarization (A-B), Sirius red (C-D) and Masson trichrome (E-F). Note increased deposition of collagen fibers in the prostatic stroma of obese mice (arrows). Scale bars: A-D: $20 \mu \mathrm{m}$; E-F: $10 \mu \mathrm{m}$. 

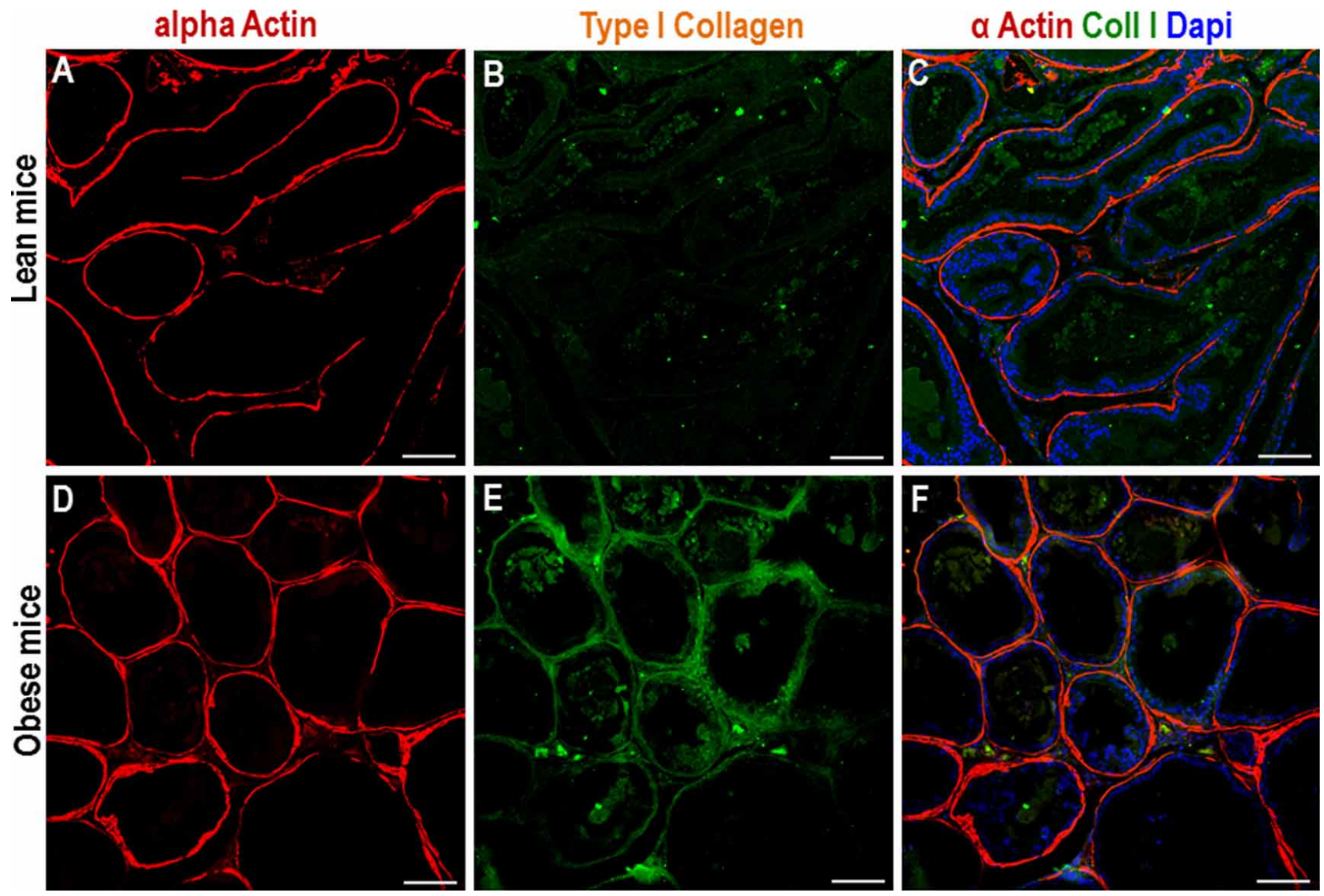

Fig. 7. Immunofluorescence of the ventral prostate of lean (A-C) and obese (D-F) mice for smooth muscle alpha-actin and type I collagen. Note increased expression of alpha-actin of smooth muscle around the acini and increase of type I collagen in the stroma of obese mice. Scale Bars: $10 \mu \mathrm{m}$.
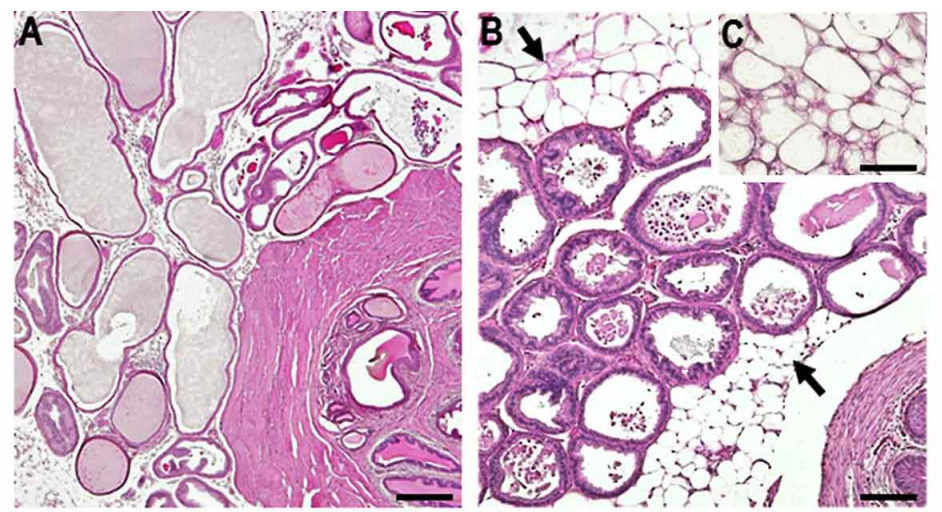

Fig. 8. Histological sections of the ventral prostate of lean $(\mathrm{A})$ and obese $(\mathrm{B}$ C) mice. Note the presence of adipose tissue surrounding the ventral prostate of obese mice (arrows) (B-C). Immunofluorescence in the adipose tissue of the prostate of obese mice. Also, expression of Interleukin 6 (IL6) and tumor necrosis factor alpha (TNF alpha) (D-F). Scale Bars: A, D, E-F: 20 $\mu \mathrm{m}, \mathrm{B}-\mathrm{C}: 10 \mu \mathrm{m}$.
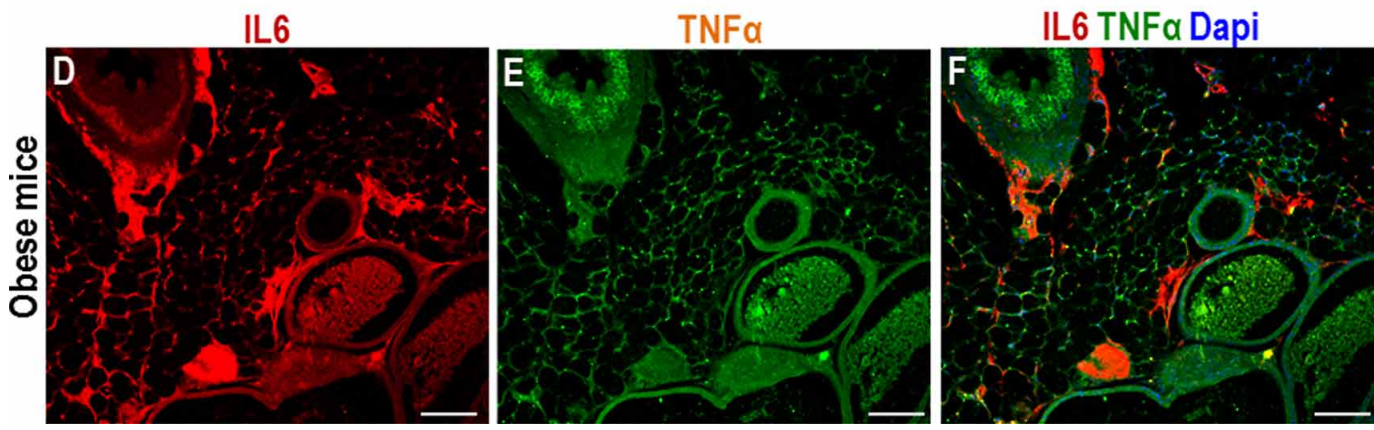


\section{DISCUSSION}

In this study, we compared the morphological and structural characteristics of the ventral prostate between lean and obese mice. We observed that the ventral prostate of the obese mice has several macroscopic and structural alterations while compared to the lean mice (Fig. 9). The ventral prostate of the obese mice had a macro and micro acinar atrophy; epithelial cell hypertrophy and the presence of cell mass in the epithelium suggestive of prostatic intraepithelial neoplasia (PIN).

Steroid hormones regulate prostate growth and physiology and modulated by multiple endocrine factors. Obesity exerts an adverse influence on this modulation and lead to several injuries that affect the prostate, including altered endocrine status, increased inflammation process and oxidative stress, all of which are favorable in the development of benign prostate hyperplasia (BPH) and cancer (Parikesit et al., 2016).

Obese ob/ob mice do not express leptin. Therefore, they are hyperphagic, hyperinsulinemic, hyperglycemic and exhibit low gonadotropin levels, incomplete development of reproductive organs and do not reach sexual maturation (Donato et al., 2011). Prostate differentiation, growth, and function are dependent on androgens. Testosterone and dihydrotestosterone exert their function through the androgen receptor (AR), which regulates the expression of several genes related to male physiology and particularly to reproductive behavior (Damas-Souza et al., 2010).

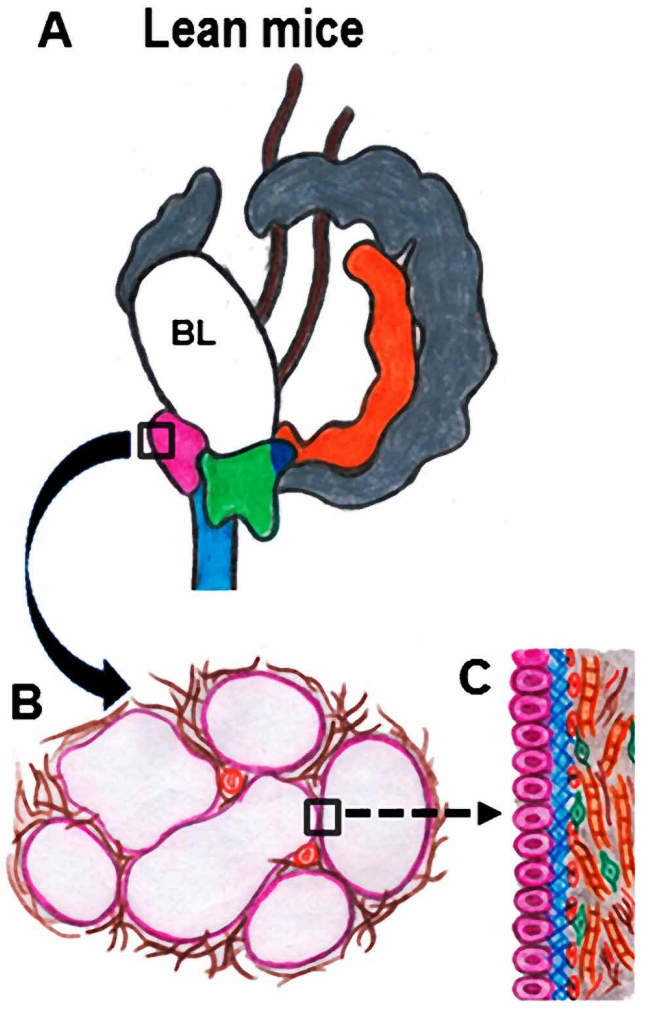

Ventral prostate

Lateral prostate

Dorsal prostate Anterior prostate

$\square$ Seminal vesicle
$\square$ Deferens ducts
$\square$ Urethra
BL: Urinary bladder

\section{Obese mice}
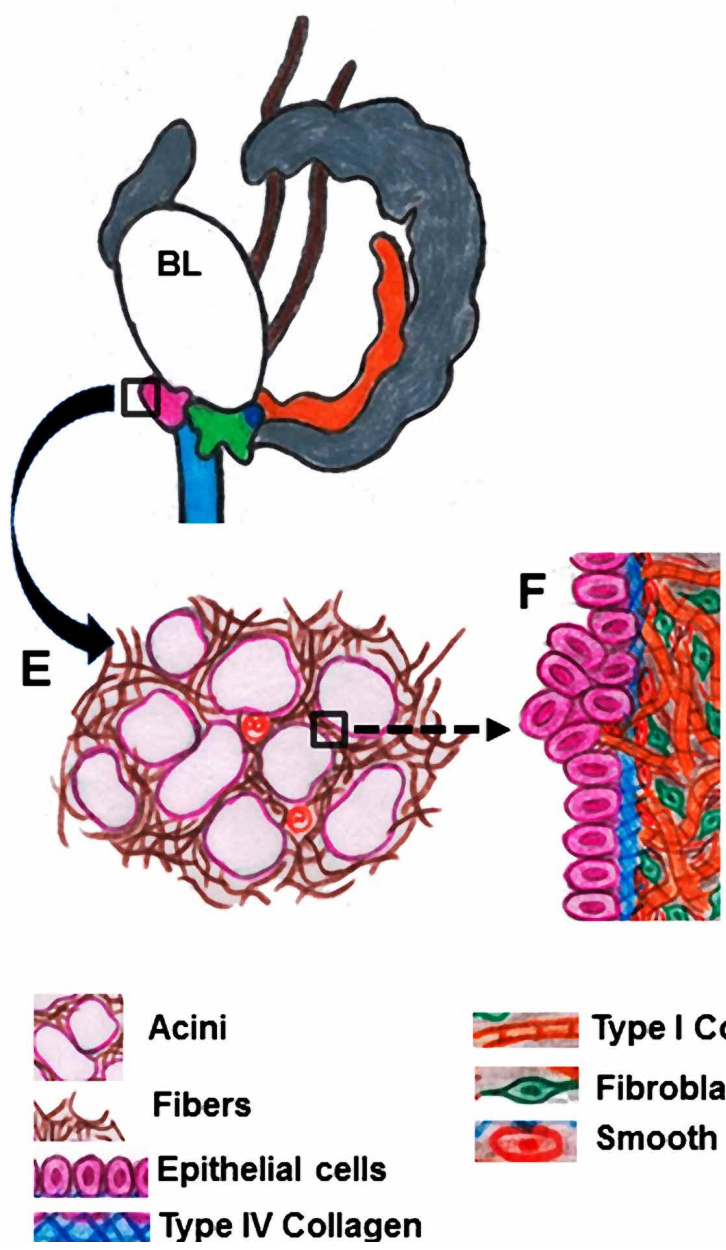

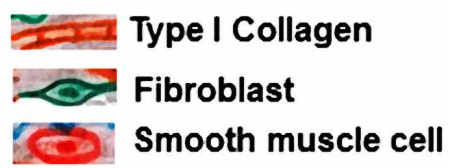

Smooth muscle cell

Fig. 9. Comparative scheme between prostate of lean (A-C) and obese mice (D-F). In the obese mice, we can see an atrophy of the ventral region (D), acinar atrophy and high stromal fiber deposition (E), high cellular activity in the extracellular matrix, hypertrophy and proliferation of the epithelial cells $(\mathrm{F})$. 
We already know that ob/ob mice have a hypothalamus deficiency about gonadotropin-releasing hormone (GnRH) secretion (Mounzih et al., 1997). Consequently, ob/ob mice have a lower release of gonadotropic hormones (follicle stimulating hormone - FSH and luteinizing hormone - $\mathrm{LH}$ ), which causes a deficit in testosterone levels in the animals (Hoffmann et al., 2016). Also, obesity and insulin resistance affect the endocrine system, alter the hypothalamus hypophyseal-gonadal hormonal axis, and depress testosterone secretion (Cunha et al., 2004). In agreement with our results, ventral prostate in a diet-induced obesity model showed acinar atrophy with epithelial hypertrophy (Ribeiro et al., 2012). The ob/ob mice have a predisposition for the development of tumors in the ventral prostate, with high cellular proliferation activity and angiogenesis (Ribeiro et al., 2010).

The negative modulation of obesity in the ventral prostate pathophysiology of ob/ob mice also seems to affect the secretory activity of the acinar epithelial cells. We identified that the secretion was primarily negative to PAS, which reveals a secretion with little or no content of glycoproteins in the ventral prostate of the ob/ob mice. Also, we observed that the ventral prostatic stroma of the ob/ob mice showed, around the acini, a deposition of type I collagen fibers, and smooth muscle cells, indicating a higher remodeling stromal activity. The prostatic stromal compartment is highly responsive to steroid hormones, especially androgens. Therefore, in response to the decline in androgens, a common prostatic response to obesity involves the stromal remodeling with changes in smooth muscle cells and increase in collagen fibers (de Carvalho et al., 1997; Wong \& Tam, 2002). The cells of the stromal microenvironment (fibroblasts and myofibroblasts) are modulated by testosterone and disturbances in the synthesis of this hormone implies deficiencies in the metabolic activity of these cells. The activities of synthesis, proliferation, adhesion of fibroblasts and myofibroblasts are compromised in the testosterone deficiency, which generates a high deposition of fibers and changes the composition of the extracellular matrix (Leach et al., 2015).

In the ventral prostate of the ob/ob mice, the dysfunction in the epithelium/stroma interaction seems to be closely associated with the regulation of adipose tissue. Recently, we have demonstrated in the brown adipose tissue of ob/ob mice a diminishing of thermogenic markers associated with reduced gene expression related to fatty acid synthesis, mobilization, oxidation, and inflammation (Martins et al.). Surrounding the ventral prostate of the obese mice, we found a significant amount of adipose tissue with inflammatory activity. Similarly, the periprostatic adipose tissue (PPA) of obese individuals has high expressions of
IL6 and TNFalpha and stimulates the prostate cancer (PCa) cell proliferation and angiogenesis, thus generating a mechanistic hypothesis to explain the worse prognosis observed in obese PCa patients (Venkatasubramanian et al., 2014).

The study provides new information about the structure of the prostate in the ob/ob mice. The data indicate that the obesity found in these animals by the absence of leptin causes an impact on the modulation of the ventral prostate, affecting cellular and structural mechanisms necessaries for the maintenance of reproductive function. Finally, we highlighted the following points in the present study:

- Obesity caused by the absence of leptin generates negative modulation in the C57BL/6J-ob/ob prostate;

- Macroscopic and histological changes are evident comparing lean vs. obese mice;

- The modifications observed in the stroma and the epithelium compromise reproductive capacity of the obese mice.

\section{ACKNOWLEDGEMENTS}

The authors would like to thank Aline Penna de Carvalho, Michele Soares, Gezileia Lau, and Thatiany Marinho for their technical assistance.

MARTINS, F. F.; DEL SOL, M.; AGUILA, B. M \& MANDARIM-DE-LACERDA, C. A. Ratones magros vs. ratones obesos: Revisión de la próstata ventral. Int. J. Morphol., 35(2):403-412, 2017.

RESUMEN: Los ratones obesos (C57BL / 6J-ob / ob) no expresan leptina y desarrollan hiperfagia, disminución del gasto energético, obesidad, hiperglucemia, hiperinsulinemia, hipotermia e infertilidad. La obesidad causa disfunción reproductiva con impacto negativo sobre la estructura prostática y la fertilidad. El objetivo de nuestro trabajo consistió en comparar la estructura y los aspectos moleculares de la próstata ventral en ratones magros y obesos (ob/ob). Se disecaron las próstatas de ratones machos obesos, de tres meses de edad, y fueron preparadas para visualizarlas por microscopía óptica e inmunofluorescencia. En comparación con el ratón magro, el ratón obeso mostró una sustancial modificación estructural en la próstata ventral comenzando con una atrofia del lóbulo ventral de la próstata. Histológicamente, los acinos mostraron una reducción de tamaño, y en el lumen, encontramos una secreción mixta PAS positiva y negativa. Los cambios epiteliales consistieron en un epitelio acinar hipertrofiado con focos de neoplasia intraepitelial. Además, se observó una marcada expresión de PCNA y Caspase3 en el epitelio, que indica tanto la 
proliferación celular como la muerte celular. El estroma mostró una alta remodelación de la matriz extracelular con marcada deposición de fibras de colágeno y células de músculo liso. Alrededor de la región ventral, se observó un aumento en la presencia de tejido adiposo. Las expresiones de interleuquina 6 y factor de necrosis tumoral alfa estaban presentes en la próstata ventral de los ratones obesos indicando inflamación. En conclusión, la obesidad modula negativamente la próstata en los ratones ob/ob, afectando directamente los mecanismos celulares y estructurales necesarios para el mantenimiento de la estructura de la próstata y la reproducción.

PALABRAS CLAVE: Colágeno; IL6; TNFalfa, Alfaactina; Reproducción; Ratón ob/ob.

\section{REFERENCES}

Berry, P. A.; Maitland, N. J. \& Collins, A. T. Androgen receptor signalling in prostate: effects of stromal factors on normal and cancer stem cells. Mol. Cell. Endocrinol., 288(1-2):30-7, 2008.

Chambers, T. J. \& Richard, R. A. The impact of obesity on male fertility. Hormones (Athens), 14(4):563-8, 2015.

Cunha, G. R.; Cooke, P. S. \& Kurita, T. Role of stromal-epithelial interactions in hormonal responses. Arch. Histol. Cytol., 67(5):417-34, 2004.

Damas-Souza, D. M.; Oliveira, C. A. \& Carvalho, H. F. Insulin affects tissue organization and the kinetics of epithelial cell death in the rat ventral prostate after castration. J. Androl., 31(6):631-40, 2010

de Carvalho, H. F.; Vilamaior, P. S. \& Taboga, S. R. Elastic system of the rat ventral prostate and its modifications following orchiectomy. Prostate, 32(1):27-34, 1997.

Donato, J. Jr.; Cravo, R. M.; Frazão, R. \& Elias, C. F. Hypothalamic sites of leptin action linking metabolism and reproduction. Neuroendocrinology, 93(1):9-18, 2011.

Hoffmann, A.; Manjowk, G. M.; Wagner, I. V.; Klöting, N.; Ebert, T.; Jessnitzer, B.; Lössner, U.; Stukenborg, J. B.; Blüher, M.; Stumvoll, M.; Söder, O.; Svechnikov, K.; Fasshauer, M. \& Kralisch, S. Leptin within the subphysiological to physiological range dose dependently improves male reproductive function in an obesity mouse model. Endocrinology, 157(6):2461-8, 2016.

Justulin, L. A. Jr.; Delella, F. K. \& Felisbino, S. L. Doxazosin reduces cell proliferation and increases collagen fibers in rat prostatic lobes. Cell Tissue Res., 332(1):171-83, 2008.

Kiernan, J. A. Histological and Histochemical Methods. $3^{\text {rd }}$ ed. Oxford, Butterworth-Heinemann, 1999.

Leach, D. A.; Need, E. F.; Toivanen, R.; Trotta, A. P.; Palethorpe, H. M.; Tamblyn, D. J.; Kopsaftis, T.; England, G. M.; Smith, E.; Drew, P. A.; Pinnock, C. B.; Lee, P.; Holst, J.; Risbridger, G. P.; Chopra, S.; DeFranco, D. B.; Taylor, R. A. \& Buchanan, G. Stromal androgen receptor regulates the composition of the microenvironment to influence prostate cancer outcome. Oncotarget, 6(18):16135-50, 2015.

Martins, F. F.; Bargut, T. C.; Aguila, M. B. \& Mandarim-de-Lacerda, C. A. Thermogenesis, fatty acid synthesis with oxidation, and inflammation in the brown adipose tissue of ob/ob (-/-) mice. Ann. Anat., 210:44-51, 2017.

Mounzih, K.; Lu, R. \& Chehab, F. F. Leptin treatment rescues the sterility of genetically obese ob/ob males. Endocrinology, 138(3):1190-3, 1997.

Parikesit, D.; Mochtar, C. A.; Umbas, R. \& Hamid, A. R. The impact of obesity towards prostate diseases. Prostate Int., 4(1):1-6, 2016.

Ribeiro, A. M.; Andrade, S.; Pinho, F.; Monteiro, J. D.; Costa, M.; Lopes, C.; Aguas, A. P. \& Monteiro, M. P. Prostate cancer cell proliferation and angiogenesis in different obese mice models. Int. J. Exp. Pathol., 91(4):374-86, 2010.

Ribeiro, D. L.; Pinto, M. E.; Maeda, S. Y.; Taboga, S. R. \& Góes, R. M. High fat-induced obesity associated with insulin-resistance increases FGF-2 content and causes stromal hyperplasia in rat ventral prostate. Cell Tissue Res., 349(2):577-88, 2012.

Venkatasubramanian, P. N.; Brendler, C. B.; Plunkett, B. A.; Crawford, S. E.; Fitchev, P. S.; Morgan, G.; Cornwell, M. L.; McGuire, M. S.; Wyrwicz, A. M. \& Doll, J. A. Periprostatic adipose tissue from obese prostate cancer patients promotes tumor and endothelial cell proliferation: a functional and MR imaging pilot study. Prostate, 74(3):326-35, 2014

Won, Y. S.; Song, J. W.; Lim, J. H.; Lee, M. Y.; Moon, O. S.; Kim, H. C.; Son, H. Y. \& Kwon, H. J. Genetically obese (ob/ob) mice are resistant to the lethal effects of thioacetamide hepatotoxicity. Toxicol. Appl. Pharmacol., 291:38-45, 2016.

Wong, Y. C. \& Tam, N. N. Dedifferentiation of stromal smooth muscle as a factor in prostate carcinogenesis. Differentiation, 70(9-10):633-45, 2002.

\author{
Corresponding author: \\ Carlos Mandarim-de-Lacerda \\ Laboratório de Morfometria \\ Metabolismo e Doença Cardiovascular \\ Centro Biomédico \\ Instituto de Biologia \\ Universidade do Estado do Rio de Janeiro \\ Av 28 de Setembro 87 fds, 20551-030 \\ Rio de Janeiro, RJ, \\ BRASIL
}

Telephone: (+55.21) 2868.8316

E-mail: mandarim@uerj.br

Received: 02-01-2017

Accepted: 16-03-2017 